\title{
The impact of selected planned motorways and expressways on the potential accessibility of the Polish-Slovak borderland with respect to tourism development
}

\author{
Daniel MICHNIAK ${ }^{\mathrm{a}}$, Marek WIĘCKOWSKI ${ }^{\mathrm{b}}$, Marcin STĘPNIAK ${ }^{\mathrm{c}}$, Piotr ROSIK ${ }^{\mathrm{c}}$
}

\begin{abstract}
Further tourism development in the Polish-Slovak borderland, as well as its overall economic development, depends on the construction of a motorway and expressway network. This paper analyses the impact of selected planned motorways and expressways (D1, A4, D3/S69, R1/R3/S7, and R4/S19) on the potential accessibility of the Polish-Slovak borderland with respect to the development of tourism. The most important investment project in Slovakia is the completion of the (started) D1 motorway. The R4/S19 and the R1/R3/S7 expressways and the D3 motorway/S69 expressway are expected to contribute to improved cross-border connections.
\end{abstract}

Keywords: transport infrastructure, motorway and expressway network, potential accessibility, tourism development, Polish-Slovak borderland

\section{Introduction}

Good quality transport infrastructure and the related transport accessibility are part of the most important prerequisites for the economic development of regions. Good accessibility of the region can help to attract new investors, who create new jobs and maintain existing ones. Transport accessibility influences many economic sectors and plays an important role in the development of tourism. The notion of accessibility can be simply defined as the ease of achieving a predetermined destination. Such destinations may be different places in which people realize key activities. From the tourists' point of view, accessibility plays an important role also in the choice of tourist destinations, such as tourist centres or tourist resorts.

Tourism is considered in many regions a key sector which should ensure socio-economic development. Besides the necessary natural and/or cultural-historical preconditions and material-technical base of tourism in tourist resorts, transport accessibility significantly contributes to the development of the region (Więckowski et al., 2012). Good transport accessibility of the region contributes to the overall attractiveness of the area from the perspective of its potential visitors and frequency of visits. On the other hand, an unfavourable level of accessibility of the region may lead to lack or outflow of tourists to better accessible regions offering similar conditions.

The significance of accessibility for the development of tourism results from the close relationship between transport and tourism. Transport is an integral part of activities in the sector of tourism. Hall (1999) identified four general spatially expressed roles of transport in tourism: transport links the source market with the host destination; it provides mobility and access within a destination area/region/country; it facilitates mobility and access within an actual tourism attraction; and, it enables travel along a recreational route which is itself the tourism experience.
Transport accessibility is often the factor that influences choice of tourist destination. When we analyse accessibility in relation to the development of tourism, it is possible to distinguish external and internal accessibility. The external accessibility of a region is the accessibility of a region from places of residences (tourist emission areas) to a place or region of stay (destination). The internal accessibility of region is the accessibility within the region or place of tourist stay, where it concerns accessibility of tourist attractions in the region or if they are large (e.g. attraction parks), it is the accessibility within the attraction. The directions and volumes of these flows are determined by a range of factors, notably attractiveness for visitors, accessibility by various means of transport, and price.

Munteanu (2010) differentiates four major types of accessibility: spatial/territorial, economic, psychological and social. Spatial/territorial (or geographical) accessibility involves the physical distance between the origin and destination places. It could be measured at least as distance accessibility $(\mathrm{km})$, time, price or potential (related to the gravity models). Economic accessibility is measured in the probable travel cost paid by the individual/group of individuals. Psychological accessibility can be expressed by the travel effort of an individual/group of individuals willing to invest in order to reach the destination, but also by the level of comfort the individual feels, by the risks they assume, etc. Social accessibility reflects the age, educational level of the individual/group of individuals, by personal and/ or social experience.

Michniak (2014) discussed selected approaches to the study of accessibility in relation to the development of tourism, which are distance-based accessibility, isochrones-based accessibility, transport infrastructure-based accessibility, accessibility based on direct public transport connections, potential accessibility, and individual accessibility. Each of these approaches has its pros and cons and their use depends

\footnotetext{
${ }^{a}$ Institute of Geography, Slovak Academy of Sciences, Bratislava, Slovakia; (corresponding author: D. Michniak, e-mail: geogmich@savba.sk)

${ }^{\mathrm{b}}$ Polish Academy of Sciences, Scientific Center in Paris, Paris, France

${ }^{\mathrm{c}}$ Institute of Geography and Spatial Organization, Polish Academy of Sciences, Warsaw, Poland
} 
on a particular research problem (e.g. its spatial scale). For the best accessibility assessment of a tourist region or centre it is necessary to combine several approaches and to use different methods of accessibility assessment. Some of them have been presented by Križan and Gurňák (2008).

Tourism has been considered an important branch of the economy in the Carpathians for many decades now, and also one that is often treated as the sole opportunity for socioeconomic development. There are favourable preconditions for the development of various kinds of tourism on the Polish-Slovak borderland and for stimulating regional development in general. The Polish-Slovak borderland is one of the regions with high tourist potential in both countries, because of the attractive natural environment (landscape morphology, rivers, lakes, caves, Protected Areas), and historical, cultural landmarks and monuments (wooden churches, castles, chateaus and native folk architecture). Tourism plays a very important role in the economy of the Polish-Slovak borderland. The number of tourists visiting this area is approximately 3.2 million a year. On the Polish part of the borderland, it exceeds 2 million tourists per year (more than $85 \%$ of them citizens of Poland). The Slovak part of the borderland was visited by almost 1.27 million visitors in 2010 . Domestic visitors made up almost two-thirds of the visitors (65.9\%), followed by tourists from the Czech Republic and Poland. On both sides of the borderland tourist flows are concentrated in the Tatra region. Other frequently-visited regions are mountainous areas such as Pieniny (including rafting), the Nízke Tatry, the Malá Fatra, the Vel'ká Fatra and the western part of the Beskides, mainly on the Polish side (the Beskid Śląski and the Beskid Żywiecki). On the other hand, the natural environment is also a certain barrier to the development of the boundary area, for example in terms of the further development of settlement and of transport infrastructure (Więckowski, 2013). Recreational and active tourism dominates in the PolishSlovak borderland - in particular, mountain hiking and climbing, skiing, cyclotourism, spa and health tourism. The mountains influence the development of specific kinds of tourism in the Carpathians. The forms of contemporary tourism in these areas are first and foremost provided by various forms of nature-oriented, leisure, adventure, health (medical), transit, cultural, gastronomic and eventoriented tourism.

There is some tourist activity going on at nearly all times of the year, but seasonality matters, with peaks in summer and winter. These peaks have been observed to extend and shift, i.e. the summer season extends towards the autumn (into October) and the winter season lasts until spring (April). Weekend and bank holiday trips have been growing in importance. Cultural tourism has also become significant, as people discover the rich cultural heritage of the mountains. In the countryside and in areas of outstanding natural beauty, countryside and nature-based tourism has developed, with agritourism and eco-tourism in particular. Traditional spa tourism is growing where mineral springs occur, but a still underestimated wellness type of development has recently supplemented this. In the area near the Polish-Slovak border, congress tourism and business trips are of secondary importance, while event tourism is significant, if underestimated. Shopping and transit tourism complete the picture in this region. Especially for new kinds of tourism in the Polish-Slovak borderland, accessibility plays an important role.
After 1989, investments in transport infrastructure in the borderland improved cross-border accessibility (newly-built cross-border roads, see Michniak, 2011) and provided an easier access from the south-west and west (new sections of the D1 motorway in Slovakia and the A4 in Poland). Further development of tourism in the Polish-Slovak borderland and the overall economy require building a motorway and expressway network in the territories of the two countries, which will communicate with the larger centres of these and neighbouring countries. The principal sources of tourists coming to this region are from the largest emission areas, such as the capitals of the two countries (Warsaw and Bratislava), and other agglomerations (e.g. Kraków, Silesia). Transport improvement is important especially for shortand medium-term tourism. Better and faster connections could facilitate decisions made by the citizens of these cities to spend a weekend in the mountains. From this point of view, the development of new infrastructure is an important process influencing tourism.

The aim of this paper is to analyse the effect of selected planned motorways and expressways on the potential accessibility of the Polish-Slovak borderland with regard to tourism development. The article presents the results of the analysis of road accessibility to the tourist destinations on the Polish-Slovak borderland. Opportunities for enhancing tourist potential through improved selected road plans are noted. Theoretical and methodological bases are introduced in the first part of the article, and then the effect of selected planned motorways and expressways (D1, D3/S69, R1/R3/ $\mathrm{S} 7, \mathrm{R} 4 / \mathrm{S} 19)$ on potential accessibility for medium-term tourism is discussed.

The Polish-Slovak borderland is defined as the area receiving support from the Cross-border Cooperation Programme, Poland-Slovak Republic 2007-2013. This area includes the entire Žilina and Prešov regions in Slovakia, and southern parts of the Silesian, Małopolskie and Podkarpackie Voivodeships in Poland (Fig. 1).

\section{Theoretical and methodological basis of potential accessibility}

One of the concepts used in defining the notion of accessibility is the concept of spatial interactions. Accessibility in this case relates to the conception of simplicity or ease of spatial interaction, the potential capacity of interaction or potential contacts with various services and functions. Goodall (1987, p. 11) reports that accessibility summarises the relative opportunity for interaction. According to Rosik (2012), potential accessibility indicates the potential of interaction between an origin and a series of destinations. It is measured by the number of activities that can be achieved in a certain time or at a certain distance, presuming decreasing linkages with increasing distance for the whole population. It is assumed that an individual preferably chooses destinations at a shorter distance. The nature of the decreasing attractiveness of a destination with increasing distance is expressed by the distance decay function, which has different shapes for different activities. McKercher and Lew (2004) and Więckowski et al. (2012) discussed the distance decay function for tourist trips. Halás et al. (2014) identified distance-decay functions for the daily travel-to-work flows.

Potential as the accessibility measure is most frequently used in the form of population (demographic) potential and as economic potential. American astrophysicist 


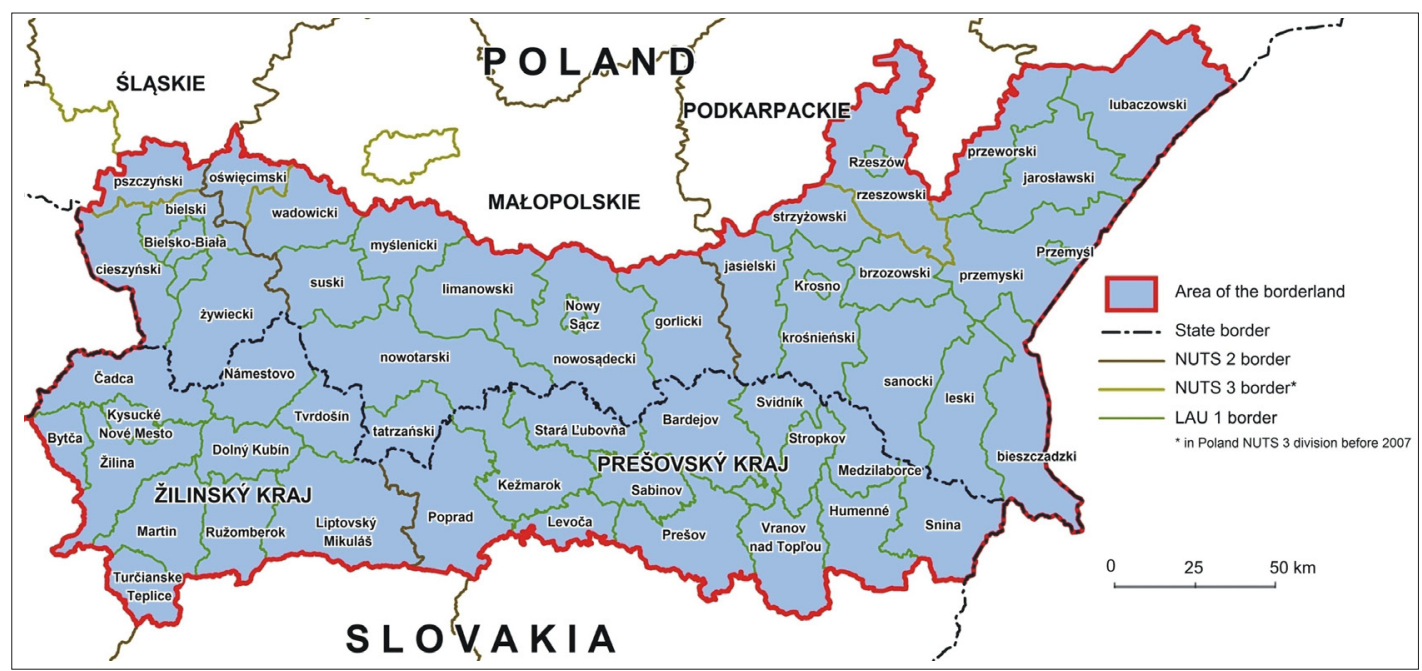

Fig. 1: The Polish-Slovak borderland. Source: authors' elaboration

Stewart (1941, 1942) formulated and disseminated the notion of population potential, defining it as a measure of a population's effect at certain distances. The population potential at a certain point represents the proximity of population to this point, i.e. the rate of possible interactions between a selected point and other points in a set of points (Goodall, 1987, p. 366).

Potential as the measure of accessibility of a certain place is the measure based primarily on gravitation (Gutiérrez, 2001), hence it inherently contains decrease of interactions with increasing distance for that particular place. Application of the potential as the accessibility measure is therefore suitable for the study of accessibility of such socio-economic activities, use of which is subject to market principles. The main drawback of the potential is the fact that the results are expressed in units which are difficult to interpret (Geertman and van Eck, 1995). For this reason potential accessibility is often expressed in percentages of mean accessibility for all zones (Spiekerman et al., 2011), or if changes in accessibility are studied, it is in percentages expressing values in the salient year $(100 \%)$ and in the target year. Establishment of the self-potential whose values are important for the overall value of potential, is also problematic (Frost and Spence, 1995; Gutiérrez and Gómez, 1999).
Following the methodology of potential accessibility computation, it is assumed that the probability of the arrival of tourists decreases with the increasing length of transport time from the place of departure to the target region. Distance-decay functions have different shapes (see, e.g. McKercher and Lew, 2003) and depend, for example, on the length of tourist stays (see Więckowski et al., 2012). The distance-decay function for medium-term tourism (2-4 days) looks like a (truncated) Gaussian curve (Fig. 2). This function could be modifiable, depending of many factors such as motivation, the type of transportation and the quality of transport networks. There are also many differences between nations and cultures. As shown by research in Western countries, people are willing to spend two to three hours travelling. Beyond this time limit, motivation to travel for leisure purposes drops dramatically. In Poland, due to the bad condition of roads and slow construction of faster motorways and expressways, the acceptable travel time is longer, namely approximately four hours (240 minutes) (Więckowski et al., 2014).

Medium- and long-term tourist stays are the only journeys for which the weight of the destination attractiveness is not expressed by a decreasing function with increasing travel time. This is caused by the fact that

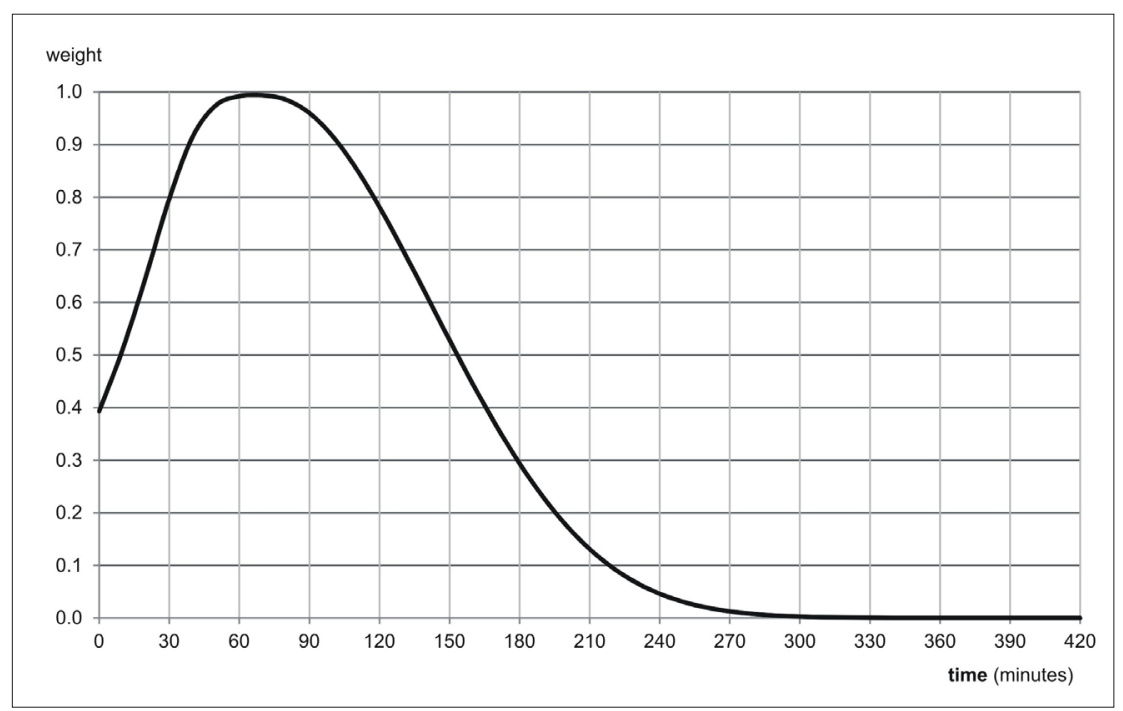

Fig. 2: Distance-decay function for medium-term tourism (2-4 days)

Source: authors' proposition 
for this type of tourism, only a limited number of tourists are willing to spend a weekend at a destination at a distance of only 30 minutes from their place of residence. This is based on the assumption that people living at a distance of 45-90 minutes drive from a destination will decide most likely for a weekend stay. The probability of selecting a more distant destination (more than 90 minutes travel) for weekend tourism decreases: at a distance of 3 hours it drops to $30 \%$ and at a distance of 5 hours it approaches zero. Very few people decide to travel by car for a weekend trip of more than five hours. Surveys have shown, however, that Poles are willing to travel even longer by car to spend a weekend in a place attractive to tourists. The curve (Fig. 2) has been modulated by using data obtained from the survey (Więckowski et al., 2012).

The potential accessibility of a tourist region refers to its accessibility by potential visitors from all over the studied area. For the analysis of potential accessibility of the Polish-Slovak borderland by car, all inhabitants of Europe were considered potential tourists, regardless of their income and real mobility.

All of Europe, together with the Polish-Slovak borderland, was divided into 133 regions, including 49 regions in the borderland (25 in Poland and 24 in Slovakia) ${ }^{1}$. Each of these 133 regions was given a mass, equivalent to the population living there. This mass was assumed to be the number of potential tourists. Centres in each region were identified. For each centre, the travel time from all centres in the Polish-Slovak borderland (49) was calculated in accordance with the time accessibility model.

The potential accessibility $A_{i}$ of a transport region $i$ in the borderland was calculated using the following formula:

$$
A_{i}=M_{i} f\left(t_{i i}\right)+\sum_{j} M_{j} f\left(t_{i j}\right)+\sum_{k} M_{k} f\left(t_{i k}\right)
$$

where

$A_{i}=$ potential accessibility of the $i$-th transport region;

$M_{i}=$ mass (population size) of the $i$-th transport region;

$M_{j}=$ mass (population size) of the $j$ - $t h$ transport region in the Polish-Slovak borderland;

$M_{k}=$ mass (population size) of the $k$-th transport region located outside the Polish-Slovak borderland;

$f\left(t_{i j}\right)=$ value of the distance decay function for travel time $t$ of an internal journey within the $i$-th transport region;

$f\left(t_{i j}\right)=$ value of the distance decay function for travel time $t$ between the transport regions $i$ and $j$; and

$f\left(t_{i k}\right)=$ value of the distance decay function for travel time $t$ between the transport regions $i$ and $k$ (c.f. Więckowski et al., 2012).

This formula describes the general potential accessibility of 49 regions (poviats in Poland and districts in Slovakia) in the Polish-Slovak borderland. The potential accessibility measure $\left(A_{i}\right)$ sums its own potential, internal potential, and external potential of the $i$-th transport region in the borderland.

\section{The impact of planned motorways and expressways on the potential accessibility of the Polish-Slovak borderland}

The base year used for the analysis of potential accessibility was 2010. Figure 3 shows values for accessibility potential for individual transport regions (LAU 1 regions - poviats in Poland and districts in Slovakia). The most accessible area (for medium-term tourism) is in the western part of the region, gradually declining to the east. The highest values of the potential accessibility index were found for the regions of Cieszyn, Bytča, Čadca, Pszczyna, Bielsko-Biała generally in the western part of the borderland - and Žilina; and the lowest were established for the regions of Sanok, Snina, Lesko, Przemyśl, Lubaczów, and Ustrzyki Dolne generally in the eastern part of the borderland. Values of the potential accessibility index depend on geographical position with respect to the principal settlement centres as modified by their demographic potential. In the case of the Polish-Slovak boundary, the most influential areas, in this sense, are the agglomerations of Upper Silesia and Kraków in Poland and the agglomeration of Ostrava in the Czech Republic. People from regions in the Czech Republic have a very short distance to the tourist destinations in Poland and Slovakia, but their personal choices are much more diversified, and the Carpathians, especially in Poland, do not constitute an important tourist region for them.

One of the issues that can be addressed using potential accessibility is the analysis of changes in accessibility due to investments in transport infrastructure (see, e.g. Stępniak and Rosik, 2013). In such cases, it is possible to compare the potential accessibility values before and after the investments. This paper analyses the impact of selected planned motorways and expressways (D1, A4, D3/S69, R1/ R3/S7, R4/S19) on potential accessibility of the Polish-Slovak borderland. Selected simulations for the most important projects are shown in Fig. 4. First, two of the selected routes (D1 and A4 motorways) are parallel to the Polish-Slovak border, and last three routes (D3/S69, R1/R3/S7, R4/S19) represent cross-border transport connections. The results show the impact on a national level (both cases) and the cross-border effect. In this contemporary meaning, inside the Schengen area, where the borders are fully open (with the exception of some examples, see Wieckowski, 2013), an interesting process shows the growth of potential accessibility to the other side of the borderland.

In the Polish-Slovak borderland, after the construction of some new expressway crossing a border, an increased potential accessibility is very visible on the Slovak side. A very large number of Polish tourists living in Kraków and from the Upper Silesian conurbation, will be located in the isochrone of two hours from the mountainous area surrounding the Tatras in Slovakia. The centres located south of the Tatras will find themselves within the reach of several-day visits from Kraków and from the Upper Silesian conurbation, as a result of the decrease in travel times. The greatest "winner" in connection with these investments will be the area of Liptovský Mikuláš. This large change will be due to the construction of the route Kraków-Chyżne-

\footnotetext{
${ }^{1}$ In the Polish-Slovak borderland, transport regions were 24 districts in Slovakia and 25 poviats in Poland. The remaining territory of Poland and Slovakia was divided into transport regions represented by NUTS 3 regions (voivodeships and regions). In the Czech Republic, Hungary and Ukraine, transport regions were defined as the NUTS 3 regions neighbouring Poland and the Slovak Republic, and the remaining areas of these countries constituted other transport regions. Each of the other European countries was regarded as a transport region.
} 


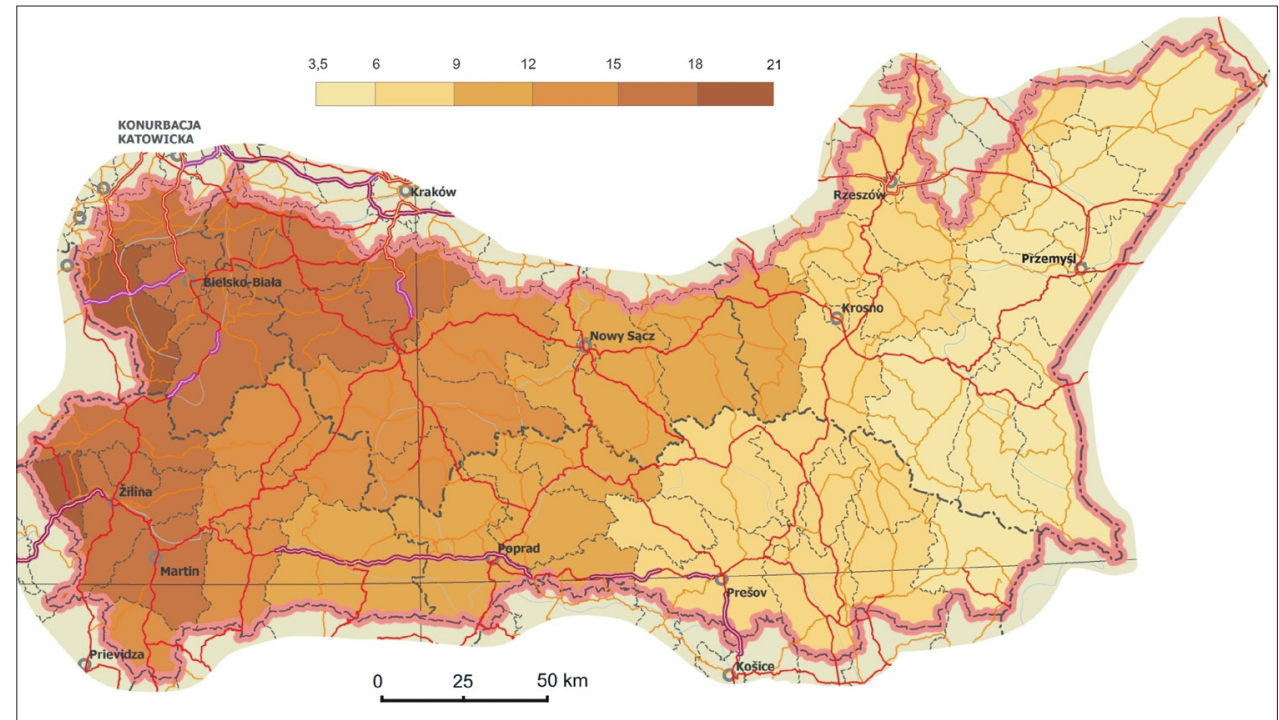

Fig. 3: Potential road accessibility in medium-term tourism in 2010 (in thousands). Source: authors' calculations
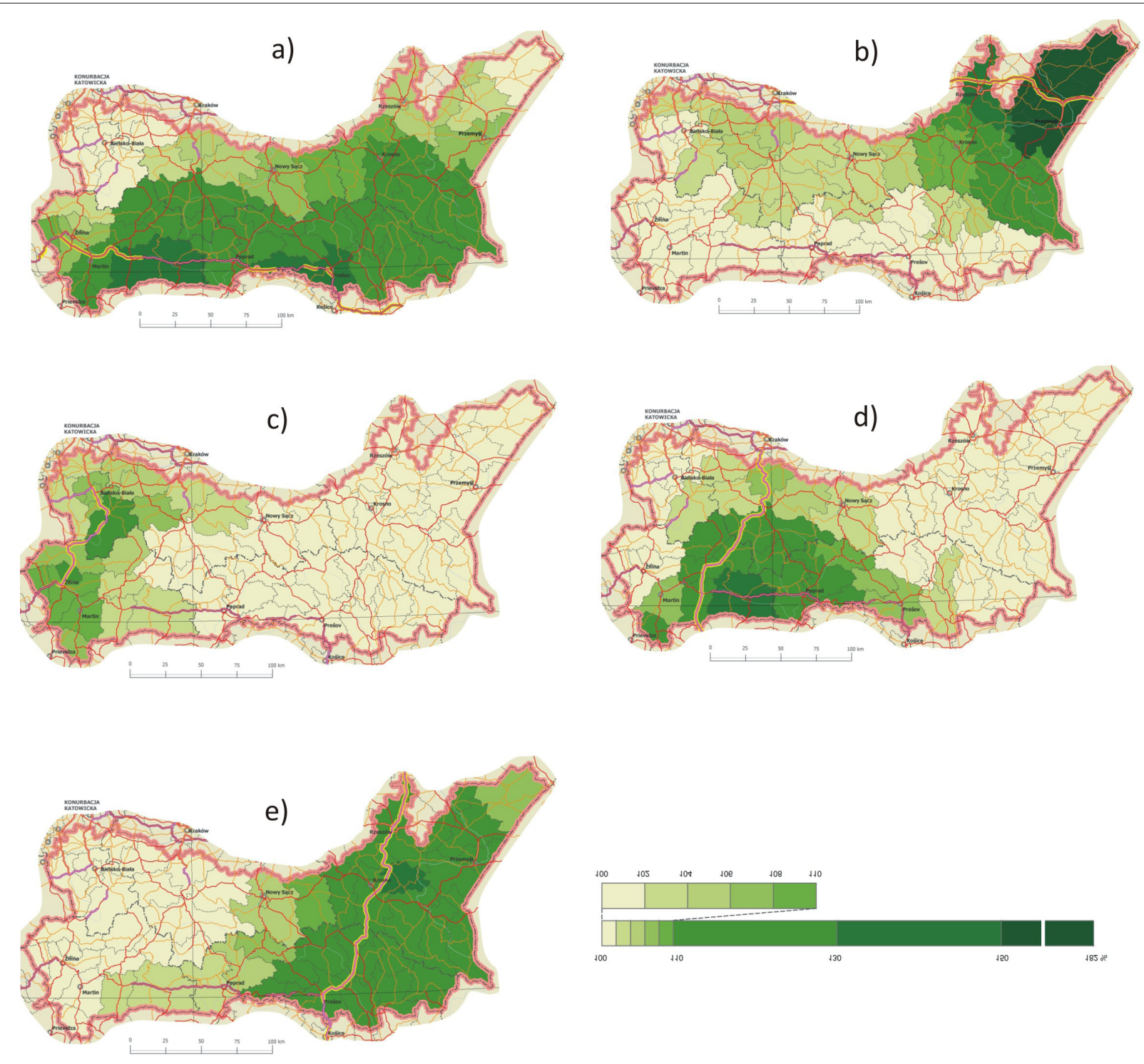

Fig. 4: Simulation of changes in potential accessibility for medium-term tourism as a result of completion of selected road infrastructure (changes in \%, $2010=100 \%$ - a) D1 motorway Hričovské Podhradie-Košice-the Ukrainian border; b) A4 motorway Kraków-Rzeszów-the border with Ukraine; c) S69 expressway and the D3 motorway BielskoBiała-Žilina; d) S7/R3/R1 Kraków-Chyżne-Ružomberok-Banská Bystrica expressway; e) S19/R4 Rzeszów-Prešov expressway). Source: authors' calculations 
Ružomberok-Banská Bystrica expressway (S7 expressway in Poland, and R3/R1 expressways in Slovakia, as shown in Fig. 4d). Analysis of this investment shows extensive spatial benefits with respect to the improvement in accessibility for medium-term tourism, and that the Slovak regions are the main beneficiaries of this investment.

The results that were obtained clearly show that the completion of the Slovak D1 motorway (Fig. 4a) will considerably contribute to the improvement of accessibility, mainly on the Slovak side of the borderland practically in all parts of the area, especially in the regions of Liptovský Mikuláš, Levoča, Prešov, and Ružomberok. The improvement of accessibility owing to this investment will also take place in the Polish part of the study area. This primarily concerns the Podhale region and peripheral regions like the Bieszczady Mountains.

It is almost exclusively Polish regions that will benefit from the completion of the parallel A4 motorway KrakówRzeszów-the border with Ukraine (Fig. 4b). The biggest improvement is observable in the northeast part of the study area near the town of Przemyśl. This investment is unimportant for cross-border tourism development. Thus, we may risk making the statement that the Slovak D1 route may result in equalisation of the potential of attractive tourist areas on both sides of the border, and potentially bring closer to the Slovak side, Vienna and even Budapest, to the Polish side of the borderland (e.g. after construction of the complete D1, the time distance from Bratislava to the Polish border in Barwinek will be approximately about $3.5 \mathrm{hrs}$ ).

The completion of the entire Bielsko-Biała-Žilina route (the S69 expressway in Poland and D3 motorway in Slovakia) would improve accessibility of the western part of the borderland, mainly the regions of Kysucké Nové Mesto, Żywiec, Bytča and Žilina (Fig. 4c).

The construction of the Rzeszów-Prešov-KošiceSlovak/Hungarian border expressway (S19 expressway in Poland and R3/R1 expressways in Slovakia), brings about considerable benefits to areas on both sides of the borderland. When the entire route is completed (Fig. 4e), significant improvement in accessibility would also be visible in the central part of the Slovak side of the borderland (Poprad), which becomes more accessible from the relatively denselypopulated areas in south-eastern Poland.

It is possible to compare the importance of individual investments in road infrastructure in terms of the number of transport regions, where the selected investment is the

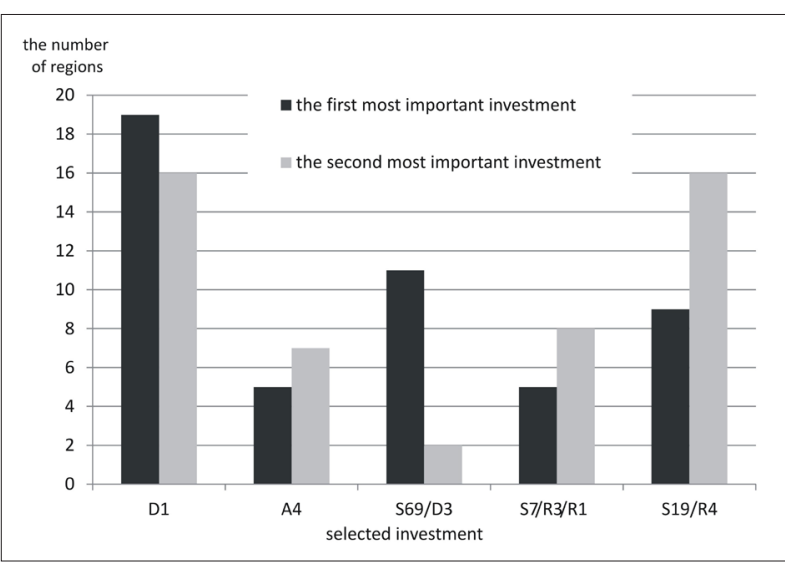

Fig. 5: Comparison of the importance of individual investments in road infrastructure Source: authors' calculations most important or the second most important (Fig. 5). The importance of individual investment has been assessed on the base of the potential accessibility value change. An investment that brought the highest improvement of the accessibility was regarded as the most important.

\section{Discussion and conclusions}

Each of the accessibility change simulations results from the comparison of the situation before completion of the expressway or motorway construction and the situation after commissioning of a given investment. It should be noted that the simulations of the influence of road network investments on potential accessibility changes in the area, were carried out on the basis of the assumption ceteris paribus, i.e. the invariability of other factors (especially in the population counts: only the current population without changes resulting from natural population increase and/or migration, were taken into account).

Therefore, it is assumed that the accessibility change results exclusively from the fact that a given road was built (or upgraded) and the speed was improved, and as result the largest part of the population will be found in the same isochrone. Other transformations resulting, for instance, from the network in terms of social or economic changes, were not part of the analysis.

The objective of the detailed simulations was to determine which of the planned investments are most significant for the particular sub-regions and tourist centres. The results obtained may be used as the basis for transport policy on the national and regional level. They may also constitute an important guideline for the policies of local authorities with respect to the development of future tourist functions (traffic forecasts), and also for lobbying for particular central government-funded investments using European Union funds. The results show the differences in tourist development potential and indicate the role of competitiveness, between tourist centres and regions, as well as countries.

The transport conditions in the entire eastern part of the Polish-Slovak borderland are unsuitable for the development of short-term tourism (Wieckowski et al., 2014). The construction of large infrastructure projects (motorways and expressways) is crucial for further development of the eastern part of the borderland. The motorways to the Ukrainian border, the D1 in Slovakia and the A4 in Poland and the Rzeszów-Prešov-Košice-Hungarian border with an expressway (the S19 and R4) should be completed first.

Out of the individual planned investments, the construction of roads belonging to the Kraków-Trstená-RužomberokBanská Bystrica traffic route (the S7, R3 and R1) is highly significant, especially for weekend tourist traffic. This will produce an improvement in accessibility from Kraków and Upper Silesia, i.e. from the areas from which the largest groups of potential tourists come.

Comparison of the advancing construction (terms of completion) of the planned expressways and motorways with the level of their effect on tourism development is rather interesting. Pursuing the existing plans, motorways D1 and A4, which are most important in terms of overall development of the whole borderland, should be finished first. Completion of the D1 is the most important investment also in terms of tourism development. As far as cross-border communications are concerned, motorway D3 and expressway S69, which are parts of the Baltic-Adriatic Corridor within the TEN-T Core Network, should be finished first, albeit this communication 
is not so important for the development of tourism. Later, the completion of expressways R4 and S19, followed by expressways R3 and S7, is planned. For the eastern part of the Polish-Slovak borderland, the construction of large infrastructure projects (the D1 and A4 motorways, and the S19/R4 expressways) is crucial in terms of the development of tourism, but also in terms of overall economic development. In the light of development of tourism in boundary areas, the expressway S7/R3/R1, planned to run close to the Tatras which is the most important tourist region in both countries, is especially important. It should be noted that the criterion of the development of tourism is not considered as the most important in planning the construction of cross-border communications. Motorways and expressways are built mainly in corridors with the largest existing and planned demands on transport, and the EU transport policy is also taken into account.

Improving accessibility does not always lead to the development of tourism activities. Good accessibility is only one of the important prerequisites for the development of tourism, which is affected by a number of different factors. Tourists tend to select destinations based on local possibilities and attractions in the first place. Good accessibility itself does not represent a source of competitiveness (Tóth and Dávid, 2010). Additionally in our differentiating world many other factors play important roles, such as the commodity of transport, price, mode, and the symbolic value of the tourism centre or region.

This article has dealt with accessibility as a positive characteristic of a region from the point of view of tourism development. But accessibility may have also negative implications. Gutiérrez (2009) states that high-value natural spaces may be in danger if a new highway is built in the area to facilitate access for the population, and that maintaining the inaccessibility of certain natural spaces is a means of protecting them. This factor underlines the role of the increasing number of potential tourists visiting the national parks (Więckowski et al., 2012; Więckowski, 2013). This is true especially in the case of tourism in protected areas, and when tourism is based on natural values. Tourism as a client-pleaser industry is in danger of destroying the environment (Sorupia, 2005). According to this author, accessibility can make or break a destination. Too much access brings in a larger number of people that can increase the level of degradation, decrease the experience, and impact the natural state of the resources. Therefore the issue of the carrying capacity of tourist regions has real importance. Another important problem related to too much access is the congestion problem. In some cases, congestion problems in high tourist seasons are a negative factor of tourism development and marketing recognition. This problem is very visible on the Polish side of the borderland, especially in the Tatras region.

In the years to come, the development of transport and an increased amount of free time, etc. will lead to more intensive competition between regions, both in terms of seeking out investors with a view to expanding tourist infrastructure (as well as other - e.g. transport - infrastructure) in order to ensure changes in the functions performed by respective centres and regions, and also in terms of attracting tourists. One specific issue is that the areas in question still have large reserves for the development of tourism at their disposal and broader dispersion of tourist traffic is essential, not only for economic growth of rarely-visited areas, but also for a reduction in congestion in those in which traffic is excessive.

\section{Acknowledgement}

This contribution has been prepared under project No. 2/0035/15: Development trajectories of localities and regions - product of sector and spatial policies, territorial capital and decisions, financed by the VEGA Grant Agency. The authors used the results of the project No. WTSL.02.01.0014-087/08 INFRAREGTUR, co-financed by the European Union's European Regional Development Fund and by the state budget within the Cross-Border Cooperation Programme, Republic of Poland - Slovak Republic, 2007-2013.

\section{References:}

FROST, M.E., SPENCE, N. A. (1995): The rediscovery of accessibility and economic potential: the critical issue of self-potential. Environment and Planning A, 27(11): 1833-1848

GEERTMAN, S. C. M., van ECK, J. R. (1995): GIS and models of accessibility potential: an application in planning. International Journal of GIS, 9(1): 67-80.

GOODALL, B. (1987): The Penguin dictionary of human geography. Harmondsworth: Penguin.

GUTIÉRREZ, J. (2001): Location, economic potential and daily accessibility: an analysis of the accessibility impact of the high speed line Madrid-Barcelona-French border. Journal of Transport Geography, 9(4): 229-242.

GUTIÉRREZ, J. (2009): Transport and accessibility. In: Kitchin, R., Thrift, N. [eds.] International Encyclopaedia of Human Geography, (pp. 410-417). Amsterdam, Elsevier.

GUTIÉRREZ, J., GÓMEZ, G. (1999): The impact of orbital motorways on intra-metropolitan accessibility: the case of Madrid's M-40. Journal of Transport Geography, 7(1): 1-15.

HALÁS, M., KLAPKA, P., KLADIVO, P. (2014): Distancedecay functions for daily travel-to-work flows. Journal of Transport Geography, 35(2): 107-119.

HALL，D. R. (1999): Conceptualising tourism transport: inequality and externality issues. Journal of Transport Geography, 7(3): 181-188.

KRIŽAN F., GURŇÁK D. (2008): Vybrané kartografické metódy znázorňovania dostupnosti. Acta Geographica Universitatis Comenianae, 51: 71-82.

McKERCHER, B., LEW, A. (2003): Distance decay and the impact of effective tourism exclusion zones on international travel flows. Journal of Travel Research, 42(2): 159-165.

MICHNIAK, D. (2011): Rozvoj cezhraničnej dopravnej infraštruktúry $\mathrm{v}$ slovensko-pol'skom pohraničí po roku 1989. In: Andráško, I., Ira, V., Kallabová, E. [eds.]: Časovo-priestorové aspekty regionálnych štruktúr ČR a SR (pp. 81-86). Bratislava, Geografický ústav SAV.

MICHNIAK, D. (2014): Vybrané prístupy $\mathrm{k}$ hodnoteniu dopravnej dostupnosti vo vztahu k rozvoju cestovného ruchu. Geografický časopis, 66(1): 21-38.

MUNTEANU, A. (2010): Conceptualizing and composing tourism accessibility. Lucrările Seminarului Geografic "Dimitrie Cantemir", 30: 125-133.

ROSIK, P. (2012): Dostępność lądowa przestrzeni Polski w wymiarze europejskim. Prace Geograficzne 233, Warszawa, IGiPZ PAN. 
SORUPIA, E. (2005): Rethinking the role of transportation in tourism. Proceedings of the Eastern Asia Society for Transportation Studies, 5: 1767-1777.

SPIEKERMANN, K., WEGENER, M., KVĚTOŇ, V., MARADA, M., SCHÜRMANN, C., BIOSCA, O., ULIED SEGUI, A., ANTIKAINEN, H., KOTAVAARA, O., RUSANEN, J., BIELAŃSKA, D., FIORELLO, D., KOMORNICKI, T., ROSIK, P. (2011): TRACC Transport accessibility at regional/local scale and patterns in Europe: applied research 2013/1/10. Luxembourg, ESPON \& Spiekermann \& Wegener, Urban and Regional Research.

STĘPNIAK, M., ROSIK, P. (2013): Accessibility improvement, territorial cohesion and spillovers: a multidimensional evaluation of two motorway sections in Poland. Journal of Transport Geography, 31(7): 154-163.

STEWART, J. Q. (1941): An inverse distance variation for certain social influences. Science, 93(2404): 89-90.

STEWART, J. Q. (1942): A measure of the influence of population at a distance. Sociometry, 5(1): 63-71.

TÓTH, L., DÁVID, L. (2010): Tourism and accessibility: An integrated approach. Applied Geography, 30(4): 666-677.
WIECKOWSKI M. (2013): Eco-frontier in the mountainous borderlands of Central Europe. The case of Polish border parks. Journal of Alpine Research / Revue de géographie alpine, 101(2): [cit. 02.06.2014]. Available at: URL: http://rga.revues.org/2107

WIĘCKOWSKI, M., MICHNIAK, D., BEDNAREKSZCZEPAŃSKA, M., CHRENKA, B., IRA, V., KOMORNICKI, T., ROSIK, P., STEPNIAK, M., SZÉKELY, V., ŚLESZYŃSKI, P., ŚWIĄTEK, D., WIŚNIEWSKI, R. (2012): Polish-Slovak borderland: Transport accessibility and tourism, Prace Geograficzne, 234, Warszawa, Instytut Geografii i Przestrzennego Zagospodarowania PAN.

WIECKOWSKI, M., MICHNIAK, D., BEDNAREKSZCZEPAŃSKA, M., CHRENKA, B., IRA, V., KOMORNICKI, T., ROSIK, P., STĘPIAK, M., SZÉKELY, V., ŚLESZYŃSKI, P., ŚWIĄTEK, D., WIŚNIEWSKI, R. (2014): Road accessibility to tourist destinations of the Polish-Slovak borderland: 20102030 prediction and planning. Geographia Polonica, 87(2): $5-26$.

Initial submission 14 July 2014, final acceptance 20 January 2015

Please cite this article as:

MICHNIAK, D., WIECKKOWSKI, M., STĘPNIAK, M., ROSIK, P. (2015): The impact of selected planned motorways and expressways on the potential accessibility of the Polish-Slovak borderland with respect to tourism development. Moravian Geographical Reports, 23(1): 13-20. DOI: $10.1515 / \mathrm{mgr}-2015-0002$. 